\title{
PENGARUH FINANCING TO DEPOSIT RATIO, NON PERFORMING FINANCING, DAN RETURN ON EQUITY TERHADAP PEMBIAYAAN MUDHARABAH PADA BANK UMUM SYARIAH DI INDONESIA
}

\author{
Dodi Okri Handoko ${ }^{1}$, Zulhelmy $^{2}$, Dian Tirta ${ }^{3}$ \& Fitria Risa ${ }^{4}$ \\ ${ }^{1,2 \& 3}$ Fakultas Ekonomi dan Bisnis, Universitas Islam Riau \\ ${ }^{4}$ Program Pascasarjana, Universitas Batam \\ Email:dodiokri@eco.uir.ac.id, zulhelmy@eco.uir.ac.id,diantirta@gmail.com, \\ fitriarisachacha5@gmail.com
}

\begin{abstract}
ABSTRAK
Penelitian ini bertujuan untuk mengetahui pengaruh Financing to Deposit Ratio (FDR), Non Performing Financing (NPF), dan Return On Equity (ROE) terhadap Pembiyaan Mudharabah pada Bank Umum Syariah di Indonesia tahun 2016-2018. Jumlah data yang digunakan adalah sebanyak 84 laporan keuangan triwulan dari 10 Bank Umum Syariah yang memenuhi kriteria sebagai sampel. Alat analisis yang digunakan dalam penelitian ini adalah SPSS versi 22. Hasil penelitian menunjukkan bahwa FDR, NPF, dan ROE secara simultan berpengaruh terhadap pembiayaan mudharabah. Besarnya pengaruh ketiga variabel independen tersebut terhadap pembiayaan mudharabah adalah $29,6 \%$ dan sisanya 70,4\% dipengaruhi oleh variabel lain di luar penelitian ini. Untuk hasil secara parsial, variabel FDR dan NPF tidak berpengaruh terhadap pembiayaan Mudharabah. Sedangkan untuk variabel ROE berpengaruh positif terhadap pembiayaan Mudharabah.
\end{abstract}

Kata Kunci : Financing to Deposit Ratio (FDR), Non Performing Financing (NPF), Return On Equity (ROE), Pembiayaan Mudharabah.

\begin{abstract}
This study aims to determine the effect of Financing to Deposit Ratio (FDR), Non Performing Financing (NPF), and Return On Equity (ROE) on Mudharabah Financing at Islamic Commercial Banks in Indonesia in 2016-2018. The amount of data used is 84 quarterly financial statements reports of 10 Islamic Commercial Banks that meet the criteria as a sample. The analytical tool used in this study is SPSS version 22. The results show that FDR, NPF, and ROE simultaneously affect mudharabah financing. The magnitude of the influence of the three independent variables on mudharabah financing is $29.6 \%$ and the remaining $70.4 \%$ is influenced by other variables outside of this study. For partial results, FDR and NPF variables have no effect on Mudharabah financing. Meanwhile, the ROE variable has a positive effect on Mudharabah financing.
\end{abstract}

Keyword : Financing to Deposit Ratio (FDR), Non Performing Financing (NPF), Return On Equity (ROE), Mudharabah Financing. 


\section{PENDAHULUAN}

Berdasarkan data dari Indopos.co.id, pengembangan bisnis keuangan syariah di Indonesia memiliki peluang begitu besar. Hal tersebut karena didukung jumlah populasi penduduk muslim terbesar ke-4 dunia, sebanyak 265 juta di tahun 2018. Hal ini tentunya akan mendorong pertumbuhan ekonomi terbesar ke-7 di tahun 2030. Dan Kepala Sub Bagian Perizinan Perbankan Syariah OJK Asep Sudirman mengatakan bahwa fenomena gelombang religiusitas kalangan milenial, public figure, profesional serta usaha industri halal, semakin berkembang dan menjadi tren antara lain di bidang fashion, farmasi dan kosmetik, food and beverage, dan lain-lain. The Most Developed Islamic Finance Market (Thomson Reuters, 2018) menempatkan Indonesia pada posisi ke-10 di dunia. Salah satu indikator yang menarik dari riset ini adalah menempatkan Indonesia rangking ke2 jumlah lembaga keuangan syariah terbanyak setelah Malaysia. Dari sisi aset, kata Asep, hingga Juni 2018 total aset lembaga keuangan syariah sudah mencapai Rp. 1,335,41 triliun atau USD 94,44 miliar (tidak termasuk saham syariah). Dari sisi market share capaiannya sebesar 8,29 persen.

Ada faktor internal dan eksternal yang mempengaruhi bank dalam meyalurkan pembiayaan. Pihak bank biasanya merujuk pada laporan keuangan bank yang digambarkan dengan bermacam rasio keuangan untuk melihat kondisi internal perusahaan. Gambaran tentang baik buruknya suatu bank syariah dapat dikenali melalui kinerjanya yang tergambar dalam laporan keuangan dan itu bisa dilihat dari beberapa rasio keuangan. Azni et al, (2016) telah melakukan penelitian yang berkaitan dengan bagaimana memprediksi kebangkrutan suatu bank umum syariah di Indonesia dengan menggunakan rasio keuangan. Hal ini penting dilakukan untuk mencegah terjadinya kebangkrutan pada bank umum syariah.
Pada tahun 2018, statistik perbankan syariah (Otoritas Jasa Keuangan, 2018) melaporkan rasio keuangan pada Bank Umum Syariah dan Unit Usaha Syariah. Dimana Financing to Deposit Ratio (FDR) mengalami penurunan nilai menjadi 78,53 $\%$. Hal ini menunjukkan angka yang kurang ideal. Idealnya Bank Syariah memiliki FDR $80 \%$ - 90\%, sesuai dengan yang dikatakan oleh Asosiasi Perbankan Syariah Indonesia (ASBISINDO). Non Perfoming Financing (NPF) mengalami penurunan nilai yang signifikan dari $5,21 \%$ pada bulan Januari 2018 menjadi 3,26\% pada bulan Desember 2018. Menurut Peraturan Bank Indonesia Nomor 6/10/PBI/2004 tanggal 12 April 2004 tentang sistem penilaian Tingkat Kesehatan Bank Umum dan Bank Syariah, semakin tinggi nilai NPF (diatas 5\%), maka bank tersebut tidak sehat. Dengan demikian NPF menunjukkan angka yang tidak sehat pada bulan Januari 2018 menjadi angka yang sehat pada bulan Desember 2018. Sedangkan nilai Return On Equity (ROE) tidak dilaporkan pada statistik perbankan syariah tahun 2018 untuk Bank Umum Syariah dan Unit Usaha Syariah.

Damayanti (2014) dalam penelitiannya menemukan bahwa tidak ada pengaruh Financing to Deposit Ratio (FDR) dan Non Perfoming Financing (NPF) terhadap pembiayaan murabahah, hasil yang diperoleh tidak sejalan dengan hasil penelitian Prastanto (2013), yang mengatakan bahwa FDR berpengaruh positif terhadap pembiayaan murabahah.

\section{TINJAUAN PUSTAKA}

\section{Mudharabah}

Asy-Syarbasyi dalam Antonio (2012) menyatakan bahwa pembiayaan mudharabah merupakan akad kerja sama usaha antara dua pihak, pihak pemodal dan pengelola usaha. Keuntungan usaha dibagi sesuai kesepakatan yang tertera pada kontrak, dan kerugian ditanggung oleh pemodal selagi kerugian bukan karena kecerobohan pengelola, apabila akibat kecerobohan pengelola maka pengelola yang bertanggung jawab. 
Secara teknis mudharabah adalah akad kerjasama usaha antara dua pihak dimana pihak pertama (shahibul maal) menyediakan seluruh modal, sedangkan pihak lainnya menjadi pengelola. (Muhammad, 2008). Perbankan syariah dalam transaksi mudharabah merupakan shahibul maal. Sedangkan nasabah yang menerima pembiayaan mudharabah, bertindak sebagai pengelola dana. (Yaya et al, 2014)

\section{Financing to Deposit Ratio}

Financing to Deposit Ratio (FDR) merupakan rasio yang mengukur kemampuan bank dalam memenuhi kewajiban keuangan. Menurut Mahardika (2015) FDR merupakan perbedaan antara anggaran yang dihimpun di sisi funding dengan jumlah dana yang diberikan dan salurkan pada sisi lending. FDR berguna untuk mengukur tingkatan likuiditas yang bermaksud mengenali kemahiran bank dalam pemberian yang maksimal dari permintaan pembiayaan bank.

Berdasarkan surat edaran Nomor 10/40/DPM tanggal 17 November 2008 Bank Umum syariah dapat mengikuti lelang SBIS jika memiliki FDR $>80 \%$. Selain itu, menurut Asosiasi Perbankan Syariah Indonesia (ASBISINDO), idealnya bank syariah memiliki FDR 80\% - 90\%. Batas toleransi FDR perbankan syariah sekitar $90 \%$, hal ini bertujuan untuk likuiditas perbankan syariah tetap terjaga. FDR perbankan syariah yang tinggi (diatas 100\%) akan menjadi ancaman serius bagi likuiditas bank syariah itu sendiri. Berdasarkan Surat Edaran Bank Indonesia Nomor 13/27/DPM 1 Desember 2011, rumus untuk menghitung FDR sebagai berikut:

$$
\mathrm{FDR}=\frac{\text { Total Pembiayaan }}{\text { Total DPK }} \times 100 \%
$$

\section{Non Performing Financing}

Non Performing Financing (NPF) menunjukkan kemampuan manajemen bank dalam mengelola pembiayaan bermasalah yang diberikan bank. Pembiayaan bermasalah adalah pembiayaan dengan kualitas kurang lancar, diragukan, dan macet. (Ma'siyah dan Mawardi, 2015). Menurut Darmawi (2018) rasio NPF ini meliputi kredit dengan keterangan bahwa peminjam tidak bisa memenuhi persyaratan kesepakatan kredit yang disepakati. Menurut Peraturan Bank Indonesia Nomor 6/10/PBI/2004 tanggal 12 april 2004 tentang sistem penilaian Tingkat Kesehatan Bank Umum dan Bank Syariah, semakin tinggi nilai NPF (di atas $5 \%$ ), maka bank tersebut tidak sehat.

Tingkat NPF dirumuskan dengan :

Non Performing Financing $=($ Total

Pembiayaan Bermasalah / Total Pembiayaan)

$$
\mathrm{x} 100 \%
$$

\section{Return On Equity (ROE)}

Return On Equity (ROE) merupakan rasio untuk mengukur kemampuan manajemen bank dalam mengelola modal yang ada untuk mendapatkan net income (Kasmir, 2014). ROE merupakan perhitungan rasio yang menunjukkan kemampuan perusahaan dalam menghasilkan laba bersih dengan memakai modal sendiri dan menghasilkan laba bersih bagi investor. Semakin tinggi nilai rasio ROE, semakin tinggi pula nilai perusahaan, hal ini tentunya merupakan daya tarik bagi investor untuk menanamkan modalnya diperusahaan tersebut.

\section{Rumus Return On Equity (ROE)} adalah sebagai berikut :

Return On Equity = (Keuntungan Netto Sesudah Pajak / Total Modal Sendiri) x $100 \%$

\section{METODE PENELITIAN}

Penelitian ini menggunakan data kuantitatif yang berupa angka-angka dari laporan keuangan bank umum syariah yang terdaftar di Bank Indonesia. Jenis data dalam penelitian ini adalah data dokumenter karena data yang digunakan merupakan data sekunder dengan studi dokumenter yang berupa laporan keuangan tahunan bank umum syariah yang terdaftar dan terpublikasi 
di Bank Indonesia dan Bank Umum Syariah pada periode 2016 sampai 2018.

Variabel independen dalam penelitian ini terdiri dari Financing to Deposit Ratio (FDR), Non Performing Financing (NPF) dan Return On Equity (ROE). Sedangkan variabel dependennya adalah Pembiayaan Mudharabah.

Populasi dalam penelitian ini adalah Bank Umum Syariah yang terdaftar di Bank Indonesia pada tahun 2016-2018. Pengambilan sampel dilakukan dengan teknik purposive sampling. Sampel yang digunakan memiliki kriteria sebagai berikut :
1. Bank Umum Syariah yang sudah terdaftar di Bank Indonesia pada tahun 2016-2018.

2. Bank Umum Syariah yang mempunyai data laporan keuangan triwulan yang berisi data lengkap selama periode 20162018 terkait dengan variabel-variabel pada penelitian ini.

Berdasarkan kriteria tersebut, maka terdapat sepuluh (10) Bank Umum Syariah yang dijadikan sampel dalam penelitian ini, seperti tampak pada tabel.

Tabel 1. Daftar nama Bank Umum Syariah yang sesuai kriteria

\begin{tabular}{cl}
\hline & Bank Umum Syariah (BUS) \\
\hline 1 & PT. Bank Muamalat Indonesia \\
\hline 2 & PT. Bank Syariah Mandiri \\
\hline 3 & PT. Bank BRI Syariah \\
\hline 4 & PT. Bank Syariah Bukopin \\
\hline 5 & PT. Bank BNI Syariah \\
\hline 6 & PT. Bank Jabar Banten Syariah \\
\hline 7 & PT. BCA Syariah \\
\hline 8 & PT. Bank Victoria Syariah \\
\hline 9 & PT. Maybank Syariah Indonesia \\
\hline 10 & PT. Bank Panin Syariah \\
\hline & Sumber: $w w w . b i . g o . i d(2020)$
\end{tabular}

Data sekunder pada penelitian ini berupa laporan keuangan triwulan Bank Umum Syariah di Indonesia pada periode tahun 2016-2018. Data tersebut diperoleh dari website resmi bank umum syariah yang ada di Indonesia yang dijadikan objek penelitian. Selain itu data juga diperoleh dari situs Bank Indonesia yaitu www.bi.go.id.

Analisis deskriptif digunakan untuk menggambarkan atau mendeskripsikan data, tanpa bermaksud mengeneralisasi atau membuat kesimpulan, dan hanya untuk menjelaskan kelompok data saja. Pada penelitian ini program data yang digunakan adalah SPSS (Statistical Package for the Social Sciences) versi 22.

\section{HASIL PENELITIAN DAN PEMBAHASAN}

\section{Uji Normalitas}

Uji normalitas dalam penelitian ini menggunakan One-Sample KolmogorovSmirnov Test dan grafik normal probabilityplot. Grafik normal probabilityplot tampak pada gambar berikut : 


\section{Gambar 1. Hasil Uji Normalitas}

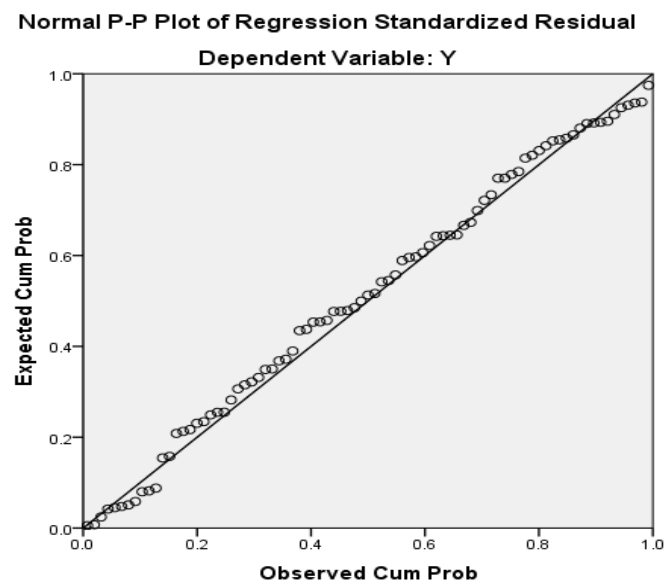

Sumber : Data Olahan (2020)

\section{Uji Multikolonieritas}

Hasil uji

multikolonieritas

menunjukkan tidak ada satupun variabel independen yang memiliki nilai tolerance kurang dari 0,10 dan tidak ada nilai Variance Inflation Factor (VIF) ketiga variabel independen yang lebih dari 10. Nilai tolerance variabel FDR (X1) adalah 0,797, NPF (X2) 0,764 dan ROE (X3) 0,735. Sedangkan nilai VIF FDR (X1) 1,254, NPF
(X2) 1,309 dan ROE (X3) 1,361. Sehingga tidak terjadi multikolonieritas dalam model regresi.

\section{Regresi Linear Berganda}

Hasil uji regresi linear berganda dalam penelitian ini tampak pada tabel berikut:

Tabel 2. Coefficients ${ }^{\mathrm{a}}$

\begin{tabular}{|c|c|c|c|c|c|c|}
\hline & \multirow[b]{2}{*}{ Model } & \multicolumn{2}{|c|}{ Unstandardized Coefficients } & \multirow{2}{*}{$\begin{array}{c}\begin{array}{c}\text { Standardized } \\
\text { Coefficients }\end{array} \\
\text { Beta } \\
\end{array}$} & \multirow[b]{2}{*}{$\mathbf{t}$} & \multirow[b]{2}{*}{ Sig. } \\
\hline & & $\mathbf{B}$ & Std. Error & & & \\
\hline \multirow[t]{4}{*}{1} & (Constant) & 147.549 & 520.463 & & .283 & .778 \\
\hline & $\mathrm{X} 1$ & -3.325 & 4.727 & -.074 & -.703 & .484 \\
\hline & $\mathrm{X} 2$ & 30.419 & 22.157 & .148 & 1.373 & .174 \\
\hline & $\mathrm{X} 3$ & 548.327 & 110.765 & .545 & 4.950 & .000 \\
\hline
\end{tabular}

Sumber : Data Olahan (2020)

Berdasarkan tabel hasil analisis mengalami kenaikan sebesar 1 maka nilai regresi berganda, maka dapat ditulis mudharabah (Y) akan mengalami kenaikan persamaan regresi sebagai berikut :

$\mathrm{Y}=147,549-3,325 \mathrm{X} 1+30,419 \mathrm{X} 2+$ 548,327 X3

Berdasarkan rumus regresi tersebut, maka dapat dinyatakan bahwa, apabila FDR (X1) mengalami kenaikan sebesar 1 maka nilai mudharabah (Y) akan mengalami penurunan sebesar 3,325. Apabila NPF (X2) sebesar 30.419. Apabila ROE (X3) mengalami kenaikan sebesar 1 maka nilai mudharabah (Y) akan mengalami kenaikan sebesar 548,327.

\section{Uji Signifikasi Simultan (Uji F)}

Uji $F$ ditunjukkan dalam tabel ANOVA berikut : 
Tabel 3. ANOVA ${ }^{\mathrm{a}}$

\begin{tabular}{clccccc}
\hline Model & \multicolumn{1}{c}{$\begin{array}{c}\text { Sum of } \\
\text { Squares }\end{array}$} & Df & Mean Square & F & Sig. \\
\hline \multirow{3}{*}{1} & Regression & 2168806.772 & 3 & 722935.591 & 11.091 & $.000^{b}$ \\
\cline { 2 - 7 } & Residual & 5149187.542 & 79 & 65179.589 & & \\
\cline { 2 - 6 } & Total & 7317994.314 & 82 & & \\
\hline \multicolumn{6}{c}{ a. Dependent Variable: Y } \\
\hline \multicolumn{6}{c}{ Sumber: Data Olahan (2020) }
\end{tabular}

Dengan nilai $\mathrm{F}$ sebesar 11,091 dan tingkat signifikansi 0,000 , maka variabel FDR, NPF, dan ROE berpengaruh terhadap pembiayaan mudharabah. Berarti hipotesis yang menyatakan bahwa FDR, NPF, dan
ROE berpengaruh terhadap pembiayaan mudharabah adalah diterima.

\section{Uji Signifikansi Parsial (Uji t)}

Hasil uji signifikansi parsial (uji t) dapat dilihat pada tabel berikut :

Tabel 4. Hasil Uji Signifikansi Parsial (Uji t)

\begin{tabular}{|c|c|c|c|c|}
\hline No. & Variabel & Hasil & Kesimpulan & Keterangan \\
\hline 1. & $\operatorname{FDR}\left(\mathrm{X}_{1}\right)$ & $\begin{array}{c}\text { Nilai } \\
\text { signifikansi } \\
0,484 \text { lebih } \\
\text { besar dari } 0,05\end{array}$ & Ditolak & $\begin{array}{l}\text { FDR secara parsial tidak } \\
\text { berpengaruh negatif terhadap } \\
\text { pembiayaan Mudharabah }\end{array}$ \\
\hline 2. & $\operatorname{NPF}\left(\mathrm{X}_{2}\right)$ & $\begin{array}{c}\text { Nilai } \\
\text { signifikansi } \\
0,174 \text { lebih } \\
\text { besar dari } 0,05\end{array}$ & Ditolak & $\begin{array}{c}\text { NPF secara parsial tidak berpengaruh } \\
\text { positif terhadap pembiayaan } \\
\text { Mudharabah }\end{array}$ \\
\hline 3. & $\operatorname{ROE}\left(\mathrm{X}_{3}\right)$ & $\begin{array}{c}\text { Nilai } \\
\text { signifikansi } 0,00 \\
\text { lebih kecil dari } \\
0,05\end{array}$ & Diterima & $\begin{array}{c}\text { ROE secara parsial berpengaruh } \\
\text { positif terhadap pembiayaan } \\
\text { Mudharabah }\end{array}$ \\
\hline
\end{tabular}

\section{Sumber: Data Olahan (2020)}

\section{Koefisien Determinasi $\left(\mathbf{R}^{2}\right)$}

Koefisien Determinasi bertujuan untuk mengetahui seberapa besar kemampuan variabel independen

Tabel 5. Model Summary

\begin{tabular}{ccccc}
\hline Model & $\mathrm{R}$ & R Square & $\begin{array}{c}\text { Adjusted R } \\
\text { Square }\end{array}$ & $\begin{array}{c}\text { Std. Error of the } \\
\text { Estimate }\end{array}$ \\
\hline 1 & $.544^{\mathrm{a}}$ & .296 & .270 & 255.30294 \\
\hline \multicolumn{4}{c}{ a. Predictors: (Constant), X3, X1, X2 } \\
\hline \multicolumn{4}{c}{ b. Dependent Variable: Y }
\end{tabular}

Sumber: Data Olahan (2020)

Nilai Adjusted $R$ Square 0,296 atau $29,6 \%$. Hal ini berarti $29,6 \%$ variabel Mudharabah dapat dijelaskan oleh ketiga variabel independen yaitu FDR, NPF, dan ROE. Sedangkan sisanya sebesar $70,4 \%$ dijelaskan oleh sebab-sebab lain di luar model. menjelaskan variabel dependen. Berikut ini adalah tabel dari koefisien determinasi penelitian ini :

\section{Pengaruh FDR terhadap Pembiayaan Mudharabah}

Nilai FDR untuk menunjukkan kemampuan bank membayar kembali penarikan dana yang dilakukan deposan melalui pembiayaan yang disalurkan sebagai sumber likuiditasnya. Penelitian ini 
menunjukkan tidak adanya pengaruh FDR terhadap pembiayaan mudharabah, dimana total pembiayaan terhadap dana pihak ketiga bukanlah yang menjadi sebab akan semakin tinggi atau rendahnya pembiayaan mudharabah. Sehingga yang membuat rendahnya minat masyarakat untuk menggunakan produk perbankan berupa mudharabah bukan dipengaruhi oleh pembiayaan yang disalurkan untuk dana pihak ketiga dari masyarakat. Hal ini ditunjukkan dengan nilai FDR pada tiap Bank Umum Syariah di Indonesia tahun 2016-2018 untuk tiap kuarternya menunjukkan rata rata nilai yang sehat diantara $80 \%-90 \%$.

Penelitian ini menunjukkan hasil uji t secara parsial tidak berpengaruh negatif terhadap pembiayaan mudharabah. Dengan koefisien regresi sebesar -0.74 dan tingkat signifikansi yang lebih besar dari 0,05 yaitu 0,484 . Dengan demikian hipotesis yang menyatakan FDR berpengaruh positif terhadap pembiayaan mudharabah adalah ditolak, karena penelitian ini menunjukkan FDR tidak berpengaruh terhadap pembiayaan mudharabah. Penelitian ini menguatkan hasil penelitian Siagian et al, (2017). Namun hasil penelitian ini bertolak belakang dengan penelitian Prastanto (2013), Damayanti (2014), Rose (2016), dimana pada penelitian mereka menunjukkan hasil FDR berpengaruh terhadap pembiayaan murabahah.

Penelitian ini menunjukkan nilai ratarata untuk variabel FDR $86,88 \%$ dan nilai Standar Deviasi 6,64\%. Nilai minimum FDR $71,87 \%$ dan nilai maximum $101,16 \%$. Nilai rata-rata FDR $86,88 \%$ menunjukkan bahwa nilai FDR pada 10 Bank Umum Syariah tergolong sehat karena rata-rata FDR masih berada di antara $80 \%-100 \%$.

\section{Pengaruh NPF terhadap Pembiayaan Mudharabah}

NPF menunjukkan tingkat presentase pembiayaan bermasalah yang dihadapi oleh bank. Guna mengurangi resiko dari pembiayaan bermasalah, pihak bank harus menurunkan jumlah pembiayaan mudharabah yang disalurkan. Jadi semakin tinggi nilai NPF maka akan menyebabkan nilai pembiayaan mudharabah semakin rendah.

Penelitian ini menunjukkan hasil uji $\mathrm{t}$ secara parsial NPF tidak berpengaruh positif terhadap pembiayaan mudharabah. Dengan koefisien regresi 0.148 dan tingkat signifikansi yang lebih besar dari 0,05 yaitu 0,174 . Berarti hipotesis yang menyatakan bahwa NPF berpengaruh positif terhadap pembiayaan mudharabah adalah ditolak, karena penelitian ini menunjukkan NPF tidak berpengaruh terhadap pembiayaan Mudharabah. Sehingga penelitian ini bertolak belakang dengan penelitian Prastanto (2013), Damayanti (2014), Siagian et al (2017) dimana pada penelitian mereka menunjukkan hasil NPF berpengaruh terhadap pembiayaan murabahah.

Penelitian ini menunjukkan nilai ratarata NPF $2,53 \%$ dan nilai standar deviasi $1,47 \%$. Nilai minimum NPF $0 \%$ dan nilai maximum $4.97 \%$. Nilai rata-rata NPF $2,53 \%$ menunjukkan nilai NPF pada 10 Bank Umum Syariah masih tergolong sehat karena rata-rata NPF masih berada di bawah 5\%. Artinya bank masih dapat mengendalikan tingkat pembiayaan yang bermasalah dengan sebaik mungkin.

\section{Pengaruh ROE terhadap Pembiayaan Mudharabah}

ROE digunakan untuk mengukur efektivitas perusahaan di dalam mengahasilkan keuntungan dengan memanfaatkan ekuitas yang dimilikinya. Penelitian ini menunjukkan hasil uji t secara parsial ROE berpengaruh positif terhadap pembiayaan mudharabah. Dengan koefisien regresi 0,545 dan tingkat signifikansi yang lebih besar dari 0,05 yaitu 0,00. Berarti hipotesis yang menyatakan bahwa ROE berpengaruh positif terhadap pembiayaan Mudharabah adalah diterima, karena penelitian ini menunjukkan ROE berpengaruh positif terhadap pembiayaan Mudharabah. Sehingga penelitian ini 
menguatkan hasil penelitian Prastanto (2013), Damayanti (2014), dan Rose (2016).

Penelitian ini menunjukkan nilai ratarata ROE $1,37 \%$ dan nilai Standar Deviasi $0,29 \%$. Nilai minimum ROE $0,67 \%$ dan nilai maximum $1.92 \%$. Menurut Lestari dan Sugiharto (2007) dalam Rinati (2008) angka ROE dapat dikatakan baik apabila lebih besar dari $12 \%$. Nilai rata-rata ROE sebesar $1,37 \%$ menunjukkan bahwa rasio ROE pada sepuluh Bank Umum Syariah tersebut masih tergolong tidak baik karena rata-rata ROE berada dibawah $12 \%$. Artinya bank memiliki tingkat profitabilitas yang tidak baik, yaitu kemampuan bank dalam menghasilkan keuntungan dengan memanfaatkan ekuitas yang dimilikinya. Sehingga penelitian ini menunjukkan ROE yang tidak baik akan mempengaruhi pembiayaan Mudharabah menjadi tidak baik juga.

\section{Pengaruh FDR, NPF, dan ROE secara simultan terhadap Pembiayaan Mudharabah}

Nilai dari suatu rasio keuangan dapat digunakan dalam membantu penilaian dari suatu bank syariah. Manfaat rasio keuangan dalam mempengaruhi besar kecilnya penyaluran pembiyaan mudharabah dapat diukur dengan signifikansi atau tidaknya pengaruh rasio keuangan terhadap pembiayaan mudharabah. Apabila rasio keuangan berpengaruh signifikansi terhadap pembiayaan mudharabah berarti rasio keuangan dapat bermanfaat untuk mempresiksi besar kecilnya pembiayaan mudharabah yang disalurkan.

Dari hasil analisis variabel independen FDR, NPF, dan ROE secara simultan mempunyai pengaruh signifikansi terhadap variabel dependen yaitu pembiayaan mudharabah. Hal tersebut dapat dilihat dari tingkat signifikansi sebesar 0,00 yang lebih kecil dari 0,05 . Hal ini sesuai dengan hipotesis yang menyebutkan bahwa FDR, NPF, dan ROE berpengaruh terhadap pembiayaan Mudharabah. Pengaruh tersebut tergolong rendah dimana variabel independen mampu menjelaskan sebesar
$29,6 \%$ terhadap variabel dependen. Hal ini mengindikasikan bahwa variabel dependen sebagian kecil ditentukaan oleh faktor independen yang digunakan dalam penelitian ini dan sisanya 70,4\% ditentukkan oleh faktor independen yang lain.

\section{KESIMPULAN}

Berdasarkan hasil penelitian yang dilakukan mengenai pengaruh FDR, NPF, dan ROE terhadap pembiayaan Mudharabah pada Bank Umum Syariah di Indonesia tahun 2016 - 2018, maka dapat disimpulkan bahwa secara parsial FDR dan NPF tidak berpengaruh terhadap pembiayaan Mudharabah, sedangkan ROE secara parsial berpengaruh terhadap pembiayaan Mudharabah. Secara simultan, FDR, NPF, dan ROE berpengaruh terhadap pembiayaan Mudharabah. $29,6 \%$ pembiayaan Mudharabah mampu dijelaskan oleh FDR, NPF, dan ROE. Namun demikian penelitian ini masih memberikan ruang bagi peneliti lain untuk menguji ulang dengan menambahkan variabel lain selain variabel di atas, karena berdasarkan $R$ Square hanya $29,6 \%$.

\section{DAFTAR PUSTAKA}

Antonio, Muhammad Syafii. 2012. Bank Syariah: Dari Teori Ke Praktik. Gema Insani. Depok.

Azni., Yuanda, Landes., M. Hatat, Zulhelmy., \& Mariyanti, Tatik. 2016. Analisis Laporan Keuangan Sebagai Alat Dalam Memprediksi Kecenderungan Terjadinya Kebangkrutan Pada Bank Umum Syariah : BNI Syariah, BRI Syariah, Mandiri Syariah, Mega Syariah, Bukopin Syariah (Suatu Studi Penggunaan Model Altman's ZScore). Jurnal Risalah, 27(01), p.19,

Damayanti, Nadia Putri. 2014. Pengaruh Financing To Deposit Ratio (FDR), Non Performing Financing (NPF) Dan Return On Equity (ROE) terhadap Pembiayaan Murabahah 
pada Bank Syariah di Indonesia. Skripsi, Jurusan Akuntansi S1 STIE Perbanas. Surabaya.

Darmawi, H. 2018. Manajemen Perbankan dari Teori Menuju Apikasi. Edisi Pertama Cetakan ke-4. PT Bumi Aksara. Jakarta.

Kasmir. 2014. Manajemen Perbankan. Rajawali Pers. Jakarta.

Ma'siyah, Rifqul., \& Mawardi, Imron. 2015. Pengaruh Kecukupan Modal, Fungsi Intermediasi, Efisiensi Operasional, Dan Pembiayaan Bermasalah Terhadap Profitabilitas (Studi pada Bank Syariah Periode Januari 2010Juli 2014). Jurnal Ekonomi Syariah Teori dan Terapan, 2(3), p. 249265.

Mahardika, Dewa P.K. 2015. Mengenal Lembaga Keuangan. Gratama Publishing. Bekasi.

Muhammad, Rifqi. 2008. Akuntansi Keuangan Syariah, Konsep dan Implementasi PSAK Syariah. P3EI Press. Yogyakarta.

Otoritas Jasa Keuangan. 2018. Statistik Perbankan Syariah Desember 2018.

Prastanto. 2013. Pengaruh Financing to Deposit Ratio, Non Performing Finance, Debt to Equity Ratio, Quick Ratio, dan Return on Equity Terhadap Pembiayaan Murabahah Pada Bank Umum Syariah di Indoensia. Skripsi, Fakultas ekonomi universitas Negeri Semarang. Semarang.

Rinati, Ina. 2008. Pengaruh Net Profit Margin (NPM), Return On Assets (ROA) dan Return On Equity (ROE) terhadap Harga Saham pad Perusahaan yang Tercantum Indeks LQ45. Jurnal Ekonomi dan Manajemen. Universitas Gunadarma.

Rose, AM. 2016. Analisis pengaruh Financing To Deposit Ratio (FDR),
Debt To Equity Ratio (DER), Return On Equity (ROE) Dan Quick Ratio (QR) Terhadap Pembiayaan Murabahah Pada Bank Umum Syariah Di Indonesia Tahun 20102013. Skripsi, Fakultas Ekonomi Universitas Nusantara Persatuan Guru Republik Indonesia. Kediri

Siagian,Yupin Kirana., Budiman, Iskandar., \& Kismawadi, Eely Ridho., 2017. Pengaruh Rasio Keuangan terhadap PembiayaanMurabahah di Bank Pembiayaan Rakyat Syariah Adeco Langsa tahun 2013-2016. IAIN Langsa. Ihtiyadh, 1(1), p. 56-78.

Thomson Reuters, 2018. Islamic Finance Development Report 2018.

Yaya, Rizal., Martawireja, Aji Airlangga., \& Abdurahim, Ahim. 2014. Akuntansi Perbankan Syariah, Teori dan Praktik Kontemporer. Penerbit Salemba Empat. Jakarta. 